\title{
Organic Poise? Capitalism as Law
}

\section{Christopher TOMLINS $\dagger$}

The commonplace according to which we are all thoroughly grounded in a particular, contingent lifeworld, so that all universality is irreducibly coloured by and embedded in that lifeworld, needs to be turned round. The authentic moment of discovery, the breakthrough, occurs when a properly universal dimension explodes from within a particular context and becomes "for-itself," and is directly experienced as universal.

The and that has characterized multi- and interdisciplinary legal scholarship over the last half century ${ }^{2}$ hides a wealth of relational variation in socio-legal theory, from instrumentalism through evolutionary functionalism, to several distinct varieties of relative autonomy, to current predilections for a "mutually constitutive" relationship between law and what lies beyond it. ${ }^{3}$ Unless, however, one embraces an entirely reductive or reflexive account of law's relationship to whatever inhabits its beyond-such that law, as such, has no separate existence at all-one must accept that the and immanent in all forms of relational theorizing necessarily identifies law as, to some determinable extent, a system, structure, discourse, and/or field of its own, coupled with, hence cognitively open to, other such systemseconomy, polity, society-but like them manifesting operative closure, which is to say that exogenous stimuli are processed according to each system's own culture, practices,

† University of California Berkeley; Berkeley Law; Jurisprudence and Social Policy Program.

1. SLAVoJ ŽižEK, Violence 152 (2008).

2. See, e.g., Edward L. Rubin, Law And and the Methodology of Law, 1997 WIS. L. REV. 521.

3. See Christopher Tomlins, How Autonomous is Law?, 3 ANN. Rev. L. \& Soc. SCI., 45-68 (2007); see also Catherine L. Fisk \& Robert W. Gordon, Foreword: "Law As ...": Theory and Method in Legal History, 1 U.C. IRvine L. REv. 519, 520-24 (2011). 
optics, language, logic, or code, in a manner sufficiently selfreferential to amount, in the strictest statement of the case, to autopoiesis. ${ }^{4}$ Thinking "from the inside out" underscores the distinction between system and environment, hence between law and society, law and economy, and so forth. ${ }^{5}$

Applying the conjunction, as is not uncommon, to law and capitalism, ${ }^{6}$ the two elements under inspection are made to appear phenomenally distinct. Of course they overlap, and much historical research has been devoted to charting the ways they overlap, when they began to overlap, the extent of their interpenetration and so forth. However, the and powerfully enforces a requirement that we think of "law" and "capitalism" as referencing ontologically distinct phenomena. History reinforces the requirement in that history supplies a substantial archive of precapitalist (hence noncapitalist) law, thus a distinct pedigree for law, an "origin" story of its own, a record confirming a separate existence, and a distinct goal. In law's stories of its own distinctiveness, the coin was once justice, but as befits a goal that can be as much procedural as substantive it is now at least as often technique, or technology. In either case, outcomes benefit from its presence. $^{7}$ For its part, capitalism, as befits a coarser

4. See generally GunTher Teubner, LAW as an Autopoietic System (Zenon Bankowski ed., Anne Bankowska \& Ruth Adler trans., 1993); Roger Cotterrell, Sociological Perspectives on Legal Closure, in Closure oR CRITIQUe 175, 175-93 (Alan Norrie ed., 1993); Michael King, The 'Truth' about Autopoiesis, 20 J. L. \& SoC'Y 218 (1993); Dimitris Michailakis, Law as an Autopoietic System, 38 ACTA SOCIOLOGIA 323 (1995).

5. Hugh Baxter, Niklas Luhmann's Theory of Autopoietic Legal Systems, 9 ANN. REv. L. \& Soc. SCI. 167, 168-69, 183 (2013).

6. See, e.g., National Deviancy Conference \& Conference of Socialist Economists, Capitalism and the Rule of Law (Bob Fine et al., eds. 1979); see also Michael E. Tigar with Madeleine R. Levy, LAW and the Rise of CaPitalism (1977); Richard L. Abel, Capitalism and the Rule of Law: Precondition or Contraction?, 15 LAW \& Soc. INQUIRY 685 (1990); David Abraham, Comment, Persistent Facts and Compelling Norms: Liberal Capitalism, Democratic Socialism, and the Law, 28 LAW \& Soc'Y REv. 939 (1994); Sally Ewing, Formal Justice and the Spirit of Capitalism: Max Weber's Sociology of Law, 21 LAW \& Soc'Y REv. 487 (1987); William J. Novak, Law and the Social Control of American Capitalism, 60 EMORY L.J. 377 (2010); David M. Trubek, Max Weber on Law and the Rise of Capitalism, 1972 WIS. L. REv. 720-53.

7. In a critique of "what becomes of law and justice in a technical age," Marianne Constable calls law's relation to justice "the traditional concerns of 
medium, is driven by price. Life is cheapened (literally) by the immanent propensity to truck, barter, and exchange (and accumulate) that we take to lie at capitalism's heart, rendered more costly when that propensity is obstructed. ${ }^{8}$

The application of systems theory seems to me quite appropriate to the determination of relations among different operative categories of action in any given society-law, economy, and so forth. But "capitalism" is not an operative category of action. It is an encompassing, holistic characterization of a particular type of society. Thus:

[c]apitalism is an economic system in which trade, industry, and the means of production are largely or entirely privately owned and operated for profit. Central characteristics of capitalism include capital accumulation, competitive markets and wage labour. In a capitalist economy, the parties to a transaction typically determine the prices at which they exchange assets, goods, and services. ${ }^{9}$

Unlike "economy," capitalism is both institutionally ("capitalist" institutions) and ideationally ("capitalism") specific. All societies have economies. Not all economies are capitalist. This means that any posited relationship between "law" and "economy" will not be constant across all types of society. In a "capitalist" society, or "under capitalism," law may well be operatively distinct from economy, but the type of law that is operative is not institutionally or ideologically distinct from the type of economy.$^{10}$ In a capitalist society, law

jurisprudence." Marianne Constable, Just Silences: The Limits and POSSIBILITIES OF MODERN LAW 111, 175-78 (2005). On law as a "technology of public action" for "state control of American capitalism," see Novak, supra note 6, at $378,391,404-05$.

8. See John Locke, Second Treatise of Government 17-31 (Richard H. Cox ed., Harlan Davidson, Inc. 1982) (1690); ADAM SMITH, AN INQUIRY INTO THE Nature AND Causes of Wealth of Nations 22-23 (Kathryn Sutherland ed., Oxford Univ. Press 1998) (1776). By "literally" I mean that a popular representation of free market efficiencies is to reckon them in terms of relatively lowered living costs and production costs, hence welfare maximization. See Bernard E. Harcourt, The Illusion of Free Markets: Punishment and the MYTH OF NATURAL ORDER 121-50 (2011).

9. WiKIPEDIA, Capitalism, http://en.wikipedia.org/wiki/Capitalism (last visited Oct. 10, 2015).

10. Isaac D. Balbus, Commodity Form and Legal Form: An Essay on the "Relative Autonomy" of the Law, 11 LAW \& Soc'y REV. 571 (1977); Bob Jessop, On 
and economy will share with each other the definition "capitalist." Both will have had prior incarnations (a precapitalist or noncapitalist economy; precapitalist or noncapitalist law) and both may exhibit remnants and vestiges of those prior incarnations (England has more immediately obvious examples of this than the United States: think, for example, of the Lord Chancellor's wig, or a Trade Union banner: both put remnants of precapitalist modes of production on display). Both, however, are continuously at work either at getting rid of-"reforming"-those remnants and vestiges, ${ }^{11}$ or, alternatively, at rendering them cognitively (and operatively) open to the type of society in which they find themselves. ${ }^{12}$

Recent Marxist Theories of Law, the State, and Juridico-Political Ideology, 8 INT'L J. Soc. L. 339 (1980); Tomlins, supra note 3, at 52-54. Thus,

[c] apitalism is a social system based on the principle of individual rights. Politically, it is the system of laissez-faire (freedom). Legally it is a system of objective laws (rule of law as opposed to rule of man). Economically, when such freedom is applied to the sphere of production its result is the free-market.

Hamid H. Kazeroony \& Agata Stachowicz-Stanusch, Capitalism and the Social Relationship: An Organizational Perspective 292 (2014). Note also that admired advocates for capitalism profess no distinction in function or ends between "law" and "economy." At least ideologically, the two systems are not operatively distinct but entirely conflated:

The moral justification of capitalism does not lie in the altruist claim that it represents the best way to achieve "the common good." It is true that capitalism does-if that catch-phrase has any meaning-but this is merely a secondary consequence. The moral justification of capitalism lies in the fact that it is the only system consonant with man's rational nature, that it protects man's survival qua man, and that its ruling principle is: justice.

Ayn RAND, What is Capitalism?, in CAPITAlism: THE UnKNown IdEAL 20 (1967).

11. As Oliver Wendell Holmes, Jr., put it:

It is revolting to have no better reason for a rule of law than that so it was laid down in the time of Henry IV. It is still more revolting if the grounds upon which it was laid down have vanished long since, and the rule simply persists from blind imitation of the past.

O. W. Holmes, The Path of the Law, 10 HARV. L. REv. 457, 469 (1897).

12. Anglophone settler-colonialist societies with capitalist economies have taken hesitant steps toward acknowledging indigenous (non-settler) forms of law that are characteristically non-capitalist. Does this contradict the argument being made? It is noticeable that jurisdictionally indigenous law's social place is highly 
So, although the critique of functionalism is correct to disparage theories of lock-step operative responsiveness between one system (law) and another (economy), ${ }^{13}$ it is worth investigating to what extent, just as "medieval law looked, smelled, and acted medieval' . . capitalist law looks, smells, and acts capitalist." 14 This is a task for legal history. ${ }^{15}$

"Looks, smells, and acts" conveys not so much function as appearance. To use the language of base and superstructure, it is superstructure that produces and reproduces base rather than the other way round. ${ }^{16}$ The content of "base" (mode of production) is mysterious, absent the communicative efforts constantly occurring in "superstructure." 17 If it relies purely on its own resources, "base" cannot tell you what it is, or where it is, or what it looks like. It cannot reproduce itself unaided. If one is going to use architectonic metaphors, for that of a foundation (base) determining the design of the

segregated and, simultaneously, both questioned jurisdictionally as "law" at all, while pressed to become cognitively (and operatively) open to settler-colonialist capitalism. See Shaunnagh Dorsett \& Shaun McVeigh, JuRISDICTION 98-115 (2012); Shaun McVeigh, Law as (More or Less) Itself: On Some Not Very Reflective Elements of Law, 4 U.C. IRVINE L. REV. 475-81 (2014); Mariana Valverde, "The Honor of the Crown is at Stake": Aboriginal Land Claims Litigation and the Epistemology of Sovereignty, 1 U.C. IRVINE L. REV. 955 (2011).

13. The classic critique of legal functionalism remains. Robert W. Gordon, Critical Legal Histories, 36 STAN. L. REV. 57 (1984).

14. Kitty Calavita, Invitation to LaW \& Society: An Introduction to the StUdy Of REAL LAW 16-20 (2010) (quoting LAW AND SOCIETY: READINGS ON THE Social Study of LaW 7 (Stewart Macaulay, Lawrence M. Friedman \& John Stookey eds., 1995)).

15. For two earlier attempts of my own, see CHRISTOPHER L. TOMLINS, LAW, Labor, AND IdEOLOGY in the EARly AMERICAN REPUBLIC xi-xvi, 26-34, 294-97 (1993); Tomlins, supra note 3.

16. See Christopher Tomlins, Toward a Materialist Jurisprudence, in 2 Transformations in American Legal History: LaW, Ideology, and Methods; EsSAYS IN HONOR OF MORTON J. HoRWITZ 196, 198-99 (Daniel W. Hamilton \& Alfred L. Brophy eds., 2010).

17. See Duncan Kennedy, The Role of Law in Economic Thought: Essays on the Fetishism of Commodities, 34 AM. U. L. REv. 939, 976-79 (1985); see also PHIL Withington, The Politics of Commonwealth: Citizens and Freemen in Early MODERN ENGLAND 11 (2005) (noting that "in addition to their civil and civic propensities" the city commonwealths (municipal corporations) of Tudor-Stuart England embodied "the communicative basis of community" which "the cartographer John Speed termed 'commerce"'). 
(super)structure erected above it let us substitute an exterior from which an interior might, indirectly, be apprehended. ${ }^{18}$ We look at the outside of the structure, which we can see, and imagine what is inside, which we can't see. ${ }^{19}$ A capitalist society is a society that appears to be capitalist. Appearances are manifested in the society's networks of communications. Law is one of the most important of those networks of communication, because law is entirely about consequential communication: who owns what, who works for whom, what an employee is, and so forth. ${ }^{20}$ Precisely for this reason-and for its enchanting capacity to fashion the results as "order, civility, justice, empowerment"-capitalism depends upon law. ${ }^{21}$

The argument is neither ahistorical nor reductive. It is not ahistorical because "capitalist law" is, simply, a description of that style of law to be found in a capitalist

18. Warren Montag, The Threat of the Outside: Althusser's Reflections on Law, in Althusser AND LAW 15, 19 (Laurent de Sutter ed., 2013).

[Althusser] has precisely upset the order of the base-superstructure model and of its hierarchy of being. Law cannot be grasped as an emanation of the state which in turn emanates from the mode of production in its material existence. . . [Q]uestions of order and priority are nothing more than a sign of a theoretical problem yet to be addressed....

Id.

19. Tomlins, supra note 16 , at 200-03.

20. Kennedy, supra note 17, at 991-1001; William S. Lewis, Althusser on Laws Natural and Juridical, in ALTHUSSER AND LAW, supra note 18, at 33, 40-41. The literature on what I am terming "consequential communication" in labor-legal history is extensive. For an early example, see JAmes B. AtLeson, VAlues AND ASSUMPTIONS IN AMERICAN LABOR LAW (1983). For a recent example, see JEANChristian Vinel, THE EMPloYeE: A POLITICAL History (2013).

21. Jean Comaroff \& John L. Comaroff, Millennial Capitalism: First Thoughts on a Second Coming, in Millennial CAPITAlism and the Culture of NeOLIBERALISM 1, 38-39 (Jean Comaroff \& John L Comaroff eds., 2001). We should note that the Comaroffs hold law to be a fetish - "a social product, not a prime mover in constructing social worlds." Id at 38. Yet the fetish is extraordinarily durable-legality is the ground upon which the "modernist nation-state" came to be, an order of dependence greatly intensified by the rise of neoliberal capitalism "because of its contractarian conception of human relations, property relations, and exchange relations, its commodification of almost everything, and its celebration of deregulated private exchange, all of which are heavily invested in a culture of legality." Id. at 39 . 
society. ${ }^{22}$ Capitalist law and capitalist society are coincident. Both express capitalism..$^{23}$ It is not reductive because comprehension of what constitutes a capitalist society is far more often to be gained from its law than its economy. ${ }^{24}$

For and, then, we can substitute as. Not capitalism and law but capitalism as law. Capitalism is unknowable absent media of communication that convey its appearances. It is inoperable absent instrumentalities that facilitate its negotiations. What are the implications of this substitution? How do we understand the two terms "capitalism" and "law" such that the one may be made an effect of the other: capitalism as law?

Walter Benjamin writes in Capitalism as Religion (his title serves as inspiration for my text), "capitalism is not merely religiously conditioned, as [Max] Weber thought, but rather [is] an essentially religious phenomenon." 25 Benjamin thus restates capitalism as in itself religious. It "serves essentially to allay the same cares, torments, troubles to which in the past the so-called religions offered answers."26 But capitalism is a particular kind of religion. Capitalism is purely cultic, simply worship; it is ritual unmediated by theology. The cult is also ubiquitous, knowing neither remission nor alternative (incessant production and consumption). Its output and consequence is Schuld

22. See Justin Desautels-Stein, The Market as a Legal Concept, 60 BUFF. L. REv. 387, 393 (2012).

23. Montag, supra note 18 , at 26-28.

24. TomLins, supra note 15, at 19-34.

25. See generally Walter Benjamin, Capitalism as Religion, in 1 WALTER BENJAMIN: SELECTED WRITINGS: 1913-1926, at 288 (Marcus Bullock \& Michael W. Jennings eds., Rodney Livingstone trans., 1996). Except where otherwise indicated, I am using Samuel Weber's translation of key passages in his Targets of Opportunity: On the Militarization of Thinking because I like it better than the translation in Selected Writings. See SAMUEL WEBER, TARGETS OF OPPORTUNITY: ON the Militarization of ThINkING 110 (2005). By identifying capitalism as a religion among the "so-called" religions, Benjamin identifies it with Christianity-indeed the fragment holds that capitalism developed as a "parasite" of Christianity "until it reached the point where Christianity's history is essentially that of its parasite." Benjamin, supra, at 289. The religion from which all "so-called" religions are distinct is Judaism.

26. WEBER, supra note 25. 
(guilt/debt), which it universalizes, extending even to God, thus destroying all possibility of redemption, all possibility of anything, indeed, apart from itself, which "hold[s] out until the end." 27

As an all-pervasive cult, capitalism replaces the preReformation phenomenological and theological world with a new mode of knowledge, knowledge of die Bilanz (the bottom line), that is, knowledge only of itself. That is, it seizes upon a specific material practice-commerce's mode of calculusand renders it utterly ubiquitous. ${ }^{28}$ "All that is conceivable" writes Samuel Weber "is continuation of the cult itself." ${ }^{29}$ All that which appears as alternative to/critique of capitalismFreudian psychology, Nietzschean philosophy, Marxist socialism-is in fact the cult itself, endlessly intensified. In this universalization of itself and its way of thinking, in the demolition of all existence, including God, lies capitalism's

27. WEBER, supra note 25 , at 122 .

28. It is important to recognize that there is no neutrality to the disenchanted "calculability" that, following Max Weber is the peculiar characteristic of the modern. See Max Weber, Science as a Vocation, in From MAX WEBER: ESSAYS IN Sociology 129, 139-40 (H. H. Gerth \& C. Wright Mills eds., trans., 1958). Modalities of measurement are material practices. For example, in her work on the legal history of money, Christine Desan has emphasized that money is no neutral medium of exchange- "independent means of measure in the market"but like all measures of quantity is preceded by the specific material practices that establish both units of account and quantification per se as a mode of action that helps "configure the world it appear[s] merely to measure." Christine Desan, Coin Reconsidered: The Political Alchemy of Commodity Money, 11 TheORETICAL INQUIRIES L. 361, 361 (2010). In the case of money, what is prior to it, setting the conditions of existence on which it is established as medium of exchange and measurement, is the mode of its creation. See Christine DeSAN, Making MoneY: Coin, CurRency, AND The Coming of CAPITAlism (2014); Christine Desan, Beyond Commodification: Contract and the Credit-Based World of Modern Capitalism, in 2 TRANSFORMATIONS IN AMERICAN LEGAL HISTORY, supra note 16, at 111, 111-42; Desan, Coin Reconsidered, supra; Christine Desan, The Market as a Matter of Money: Denaturalizing Economic Currency in American Constitutional History, 30 LAW \& SOC. INQUIRY 1 (2005); see also Wendy Nelson Espeland \& Berit Irene Vannebo, Accountability, Quantification, and Law, 3 ANN. REV. L. Soc. SCI. 21, 22, 38-41 (2007); Wendy Nelson Espeland \& Mitchell L. Stevens, Commensuration as a Social Process, 24 AnN. Rev. Soc. 313, 313 (1998). See generally Mary PoOvey, A History OF THE MOdern FaCt (1998); MARY POOVEY, Genres of the Credit Economy: Mediating Value in Eighteenth- AND NineteENTH-CENTURY BRITAIN (2008).

29. WEBER, supra note 25, at 115. 
hope for itself: it leaves no alternative. ${ }^{30}$ Samuel Weber comments:

By translating all phenomena into the quantitative relation of the
bottom line, [capitalism] "destroys" their qualitative specificity,
"kills" their immediate self-presence, yet at the same time
"redeems" them as (commodity) value. From the point of view of
traditional "dogma,"31 such knowledge is seen as strictly
destructive, "dissolving" the "natural" connections of phenomena
with the world. "But for us," Benjamin writes... it is "both
redeeming and lethal."32

Once installed and universalized, commercial calculation becomes the link between the faith of the individual worshipper and the cult's "salient trait," which for Benjamin is the interest-bearing function of money. ${ }^{33}$ This, the capacity of money to price itself, hence endlessly generate more of itself from itself, and not the production of surplus value, is in Benjamin's text what identifies capitalism. "It is possible, indeed inevitable," Samuel Weber continues, "to "hold out until the end' once that 'end' is determined as the bottom line, for each bottom line ends one balance sheet and begins another. The process is in principle infinite and yet immanent." ${ }^{35}$

Capitalism as Religion is not an explanation but rather a cosmology, and as such a forerunner of what Benjamin would later call a dialectical image, or dialectics at a standstill- "a constellation saturated with tensions." ${ }^{36}$ Nevertheless, it provokes one to ask how capitalism

30. Id. at 115,123 . In Freud, "what has been repressed, the idea of sin, is capital itself, which pays interest on the hell of the unconscious." Benjamin, supra note 25 , at 289 . In Nietzsche, "the superman is the man who has arrived where he is without changing his ways." Id. In Marx, "the capitalism that refuses to change course becomes socialism by means of the simple and compound interest that are functions of Schuld." Id.

31 . This is a reference to pre-Reformation theology.

32. WEBER, supra note 25 , at 122.

33. Id. at 119.20; see also Judith Grbich, The Problem of Fetish in Law, History and Postcolonial Theory, 7 LAW TeXT Culture 43, 62-66 (2003).

34. WEBER, supra note 25, at 120.

35. Id. at 123. As a technicality of accountancy, Weber here confuses "balance sheet" and "income statement." The potency of the metaphor remains clear.

36. Walter Benjamin, The Arcades Project 475 (1999). 
undertakes these operations, of translation and installation, of destruction and redemption? Capitalism is not an anthropomorph. If it is "essentially religious," even if its religiosity is only so-called, should one think of it as a system of belief? As a cult, after all, what is decisive is not the "truth" of its model of knowledge, its units of account, its quantifications and translations, but faith in that model-its endless reaffirmation. If so, how is the belief system manifested? How is the knowledge of Bilanz communicated and generalized? How is faith affirmed?

We might think of the law that expresses capitalismcapitalist law - as thought and speech in the language of Bilanz forming the nexus between the faith of the worshipper and that which is worshipped, the mode of transmission that actually does the work of translating, installing, destroying, and redeeming, that neutralizes and naturalizes (renders "true") the units of account. ${ }^{37}$ Benjamin places law in the creaturely domain of guilt/debt, which is decisively separate from religion in its one true (that is, not "so-called") sense. ${ }^{38}$ "By implication, ... the cult-religion of capitalism functions entirely within the (pagan) juridical order, which it both hypostasizes and universalizes...."39 The "it" here is ambiguous. Does the cult-religion hypostasize and

37. "Law provides a rich and diverse language of accountability," write Espeland and Vannebo, and quantification has always been one of accountability's prime techniques. Espeland \& Vannebo, supra note 28, at 21-22.

[Q] uantification is rarely the neutral intervention that we might wish for, nor does it always produce disinterested knowledge.... Each instance of quantification has a particular history; the meanings of systems of classification that permit quantification are relative; numerical precision and accuracy are not the same thing; quantification possesses its own distinctive biases; and "statistics were political before they were quantitative."

Id. at 39 .

38. See Benjamin, supra note 25. Throughout Benjamin's corpus, "true" religion-beyond the profane-is the locale of redemption (the completion of all history). See, e.g., Theological-Political Fragment, in WALTER BENJAMIN: SELECTEd WriTinGS, 1935-38, at 305-06 (Howard Eiland \& Michael W. Jennings, eds., 2002). If it is the hope of the cult of capitalism to "hold out until the end," it is the Kingdom of God that is "from the standpoint of history ... the terminus [Ende]." Id. at 305.

39. WEBER, supra note 25 , at 116 . 
universalize law? Or does the juridical order hypostasize and universalize the cult-religion? To the extent that word gives voice to belief, law here seems prior. One can have knowledge of the interior only through the exterior appearance that renders it knowable. Or in other words it is the surface that matters. There is no need to go burrowing for shards of law's servitude to capitalism-examples of law as functionalist instrumentality-although obviously one can find examples if one wishes to do so. ${ }^{40}$ Rather, seeing is believing.

A distinct approach to the foregoing stresses that "Capitalism as Religion" is more straightforwardly an expression of Benjamin's long-standing interest in commodity fetishism. "Benjamin argues that capitalism is perhaps the most extreme of all religious cults founded as it is upon a purely psychological relationship to fetishized objects. Devoid of doctrine or theology, the cult maintains itself solely through the permanent celebration of its ritesshopping and consumption." ${ }^{41}$ This raises the same questions as above, but in a somewhat different form: whether the fetishization of law so evident as an accompaniment to capitalism's emergence, and even more its maturity, identifies law as one more instantiation of capitalism's "purely psychological" relationship to the objects of its attention, an object like all those others celebrated in ceremonies of veneration and consumption, an object capitalism renders so relentlessly ubiquitous that nothing that cannot be expressed in law exists; or whether it is law that is the hypostasizer and universalizer of capitalism. ${ }^{42}$ Duncan Kennedy's work on commodity fetishism emphasizes

40. See TomLINS, supra note 15 , at xiv \& n. 8 .

41. Howard Eiland \& Michael W. Jennings, Walter Benjamin: A Critical LIFE 149 (2014).

42. The reader will find the question debated in, for example, P.S. ATIYAH, THE Rise and Fall of Freedom of Contract (1979); MoRTon J. HoRWITZ, The Transformation of AmErican LaW: 1780-1860 (1977); Morton J. Horwitz, The TRANSFORMATION OF AMERICAN LAW: 1870-1960 (1992); Ritu Birla, Law as Economy: Convention, Corporation, Currency, 1 U.C. IRVINE L. REV. 1015 (2011); Comaroff \& Comaroff, supra note 21; Roy Kreitner, Money in the 1890s: The Circulation of Politics, Economics, and Law, 1 U.C. IRvine L. Rev. 975-1013 (2011); Christopher Tomlins \& John Comaroff, "Law As . ..": Theory and Practice in Legal History, 1 U.C. IRVINe L. REv. 1039, 1060-67, 1069, 1073-78 (2011). 
the latter, hence is in accord with the previous paragraph's attention to law as a language of consequence. But simultaneously, Kennedy renders commodity fetishism as legally-induced false consciousness. Law's constitutive character in relation to the commodity mode of production takes the form of "naturaliz[ing] outcomes that are in fact contingent on the peculiar mode of social organization of production through commodity ownership." ${ }^{43}$ As such, law is an agency of cognitive blockage, of "false necessity." ${ }_{44}$ The false legal consciousness characteristic of commodity production "is in an important sense a cause as well as an effect of the mode of production. This completes the dialectical circle: thought constitutes as well as being constituted by the social world it seems merely to reflect." 45

Both variations are potent for legal historians, but they are distinct in their implications for "capitalism as law." Crudely, the choice lies between emphasizing consciousness on the one hand, structure on the other. In Kennedy's case, as we have seen, law instantiates a consciousness that (a) falsely supposes that value is inherent in commodities rather than arising from social decisions about production and distribution, and consequently (b) privileges the realization of value as a return exclusively to commodities' "guardians," who recognize each other as "owners of private property" and engage in value-realizing market exchanges as such, rather than as a return to society. ${ }^{46}$ The critic's role is to "break [ ] up the 'law block' by recognizing the internal incoherence of legal doctrine, and the contingent constitutive role of law makers at all levels," ${ }^{47}$ thereby exposing law's false necessity. In exposing false necessity, the critic reveals the existence of opportunities in the legal system for oppressed groups to gain concessions.

43. Kennedy, supra note 17, at 991.

44. Id. at 1001.

45. Id. at 991-92.

46. Id.

47. Id. at 997-98 n.3 (citing Robert Brenner, Agrarian Class Structure and Economic Development in Pre-Industrial Europe, 70 PAST \& PRESENT 30-75 (1976)). 
These [concessions] are not anomalies or deviations from the inner logic of capitalist law, but rather an inflection of the course of a moving project. They destroy the "symmetry" or "coherence" of law only for those on the right and the left who start with a mistaken conception of how legality works. There is neither a built-in limit to how far concessions can go, nor an inevitable process of unraveling if they go too far. ${ }^{48}$

Law is thus on the one hand deeply implicated in capitalism, but on the other not necessarily so. For those who know "how legality works," law can be made to yield potentially unlimited, hence utterly transformative, concessions for oppressed groups.

Benjamin seems to me headed in a different direction. The cult is not a "purely psychological" phenomenon manifested solely in shopping and consumption-its object of worship is die Bilanz. Nor is the cult's persistence a function of category error, or of fundamental mistakes in cognition. We may encounter capitalism only as transitive effectsfragmented, particularized, fluid, evanescent-which materialize in our plural worlds of experience (economic, political, cultural, legal). But capitalism per se is intransitive: it exists independently of our awareness of it. ${ }^{49}$ As a realm of activity the capitalist mode of production sets conditions for the existence of knowledge-including knowledge of itself. ${ }^{50}$

48. Id.; see G. R. Rubin \& David Sugarman, Introduction: Towards a New History of Law and Material Society in England 1750-1914, in LAW, ECONOMY AND Society, 1750-1914: Essays IN THE History OF ENGLISH LAw 1-123 (G. R. Rubin \& David Sugarman eds., 1984); E. P. Thompson, The Moral Economy of the English Crowd in the Eighteenth Century, 50 PAST \& PRESENT 121 (1971).

49. See Christopher Tomlins, Afterword: Constellations of Class in Early North America and the Atlantic World, in Class MATTERS: EARLY NORTH AMERICA AND THE ATlantic World 213 (Simon Middleton \& Billy G. Smith eds., 2008); Christopher Tomlins, Subordination, Authority, Law: Subjects in Labor History, 47 INT'L LAB. \& WORKING ClaSs Hist. 56, 78-80 (1995).

50. Tomlins, Afterword, supra note 49 , at $308 \&$ n.34. (One might propose that capitalism sets conditions for the existence of knowledge in a manner analogous to astrophysical phenomena that "bend" light by the gravitational pull of their presence. First, one cannot observe the totality of the phenomenon, but its presence is theorizable by observation of the effect. But second, what one can observe must be recognized as a produced effect. From the observation one 
Most important, commodity fetishism is not false consciousness. As Arthur Ripstein puts it, "the problem is not that social relations between people seem to be relations between things, but that in an important sense they are relations between things." 51

For Marx, Ripstein argues, the world is the product of human activity (material practice), and activity comes before understanding. People interact with the world in two waysnaturally in interaction with natural conditions, and socially, in interaction with social institutions. Natural interactions involve people in their relation to things; that is, in relations operating independently of the will of any individual, such as, for example, a farmer trying to cope with the weather. In contrast, social interactions involve relations between people, hence some degree of mutual acknowledgment and reciprocation, rather than operating independently of human will.

If knowledge is thought of as the primary mode of human interaction with the world, a possible dimension for criticism of social systems presents itself: how knowledgeable or error prone are people in that social system? But if activity is considered primary, a rather different mode of criticism becomes possible. Mistaking human institutions for natural forces is the failing associated with the virtue of knowledge. Fetishism-being confronted by a relation between people as ... a relation between

constitutes knowledge, but only partial knowledge, for the effects observed can never comprise the totality of the phenomenon).

51. Arthur Ripstein, Commodity Fetishism, 17 CAN. J. OF PHIL. 733, 738-39 (1987). Kennedy successfully answers one of Ripstein's criticisms of the "fetishism as false consciousness" approach. Ripstein writes:

The fact that capitalism engenders illusions, and the manner in which it does so, is germane to understanding its workings .... Yet in discussing commodity fetishism, Marx stresses neither the mechanism of its origin nor its ideological role. Instead he describes it in a tone from which the reader is expected to recognize that the existence of fetishism is an indictment of capitalism.

Id. at 738. In fingering law and legal consciousness, Kennedy has identified both mechanism and ideological role. However, the question of capitalism as law/capitalist law remains open so far as effects are concerned. 
things-is the failing associated with practical involvement in the world. ${ }^{52}$

The capitalist market is a relation between people, but functions radically differently from ordinary social interactions, such as language.

Each individual faces the labor [or product] market in just the way [a farmer] faces the weather. The market sets parameters within which one must operate. And the only way to turn those parameters to one's advantage is the same as the only way to turn the weather to one's advantage - by exploiting their very inexorability. ${ }^{53}$

One faces the market as one faces a natural force. Knowledge that it is not a natural force makes no difference to one's situation:

The parallel between religious fetishism and commodity fetishism should now be clear. Religion arises at the level of thought; so does the religious fetish, when people are ruled by the products of their minds. Commodity production takes place at the level of practice; so does the commodity fetish, when people are ruled by the products of their hands. Religion is inseparable from religious fetishism because at bottom the institution and the fetish are identical. Commodity production and commodity fetishism are inseparable because at bottom the market and the fetish are identical. The more the market brings nature under human control, the less it is itself controllable: "In a word, it creates a world after its own image." 54

Ripstein's uncontrollable, unredeemable market potently recalls Benjamin's relentlessly recurrent, endlessly expansionist Bilanz. ${ }^{55}$ Placing activity prior to understanding does not relegate law to afterthought. Instead it requires that our jurisprudence be materialist in conception. ${ }^{56}$ Most important, Ripstein offers us an alternative reading of "capitalism as law" to Kennedy's contingency-law that is at

52. Id. at 743 (emphasis added).

53. Id. at 746 .

54. Id. at 748 (citing Karl MarX \& Frederick ENGels, Manifesto of the COMMUNIST PARTY 13 (1848).

55. For potent illustration, see Jonathan Levy, Freaks of Fortune: The EMERGING WORLD OF CAPITALISM AND RISK IN AMERICA 150-90 (2012).

56. See Christopher Tomlins, Historicism and Materiality in Legal Theory, in Law, Theory, AND History: A Neglected Dialogue (Maksymilian Del Mar \& Michael Lobban eds., forthcoming July 2016); see also Tomlins, supra note 16. 
once false necessity, yet always indeterminate, hence also potentially transformative. As a social, not a natural, relation, the endlessly expanding, uncontrollable capitalist market requires human expression. Its expression lies in law, just as Kennedy would predict. But the essence of capitalism as law is not consciousness but structure. A second look with new eyes will not change what one sees.

To think of law structurally is to imagine a language of consequence that produces effects. In a capitalist society the effects it produces are manifestations of a system of action called capitalism that exists independently of law but is knowable only through the operations of law. Perhaps this is circular, but I think not. ${ }^{57}$ Rather, "[w]e cannot draw closed the net in which we stand," as Benjamin writes, intriguingly, at the very outset of his fragment. ${ }^{58}$

If the argument is not circular then our conclusion might be that to study capitalism as law is to study a relationship of "organic poise." 59 To study that relationship historically, however, also offers the opportunity to identify moments when, as Žižek puts it, "in certain specific social conditions of commodity exchange and global market economy, 'abstraction' becomes a direct feature of actual social life" that "impacts on the way concrete individuals behave and relate to their fate and their social surroundings." ${ }^{00}$ This

57. I prefer to think of it as an attempt to rescue "capitalism" as an aggregate phenomenon, amenable to examination as such, from the scholarly disaggregation that has seen "capitalism" as such replaced by a plurality of ever more specified and differentiated phenomena.

58. WEBER, supra note 25 , at 110-12. The expression suggests a desire to take a stand, and an awareness both that the footing is difficult and the dimensions of the task formidable. For the present, says Benjamin, one must be content with a statement rather than a demonstration. $I d$.

59. ŻIžEK, supra note 1 , at 50. Organic poise is that condition of being which precedes its own disruption, that which is prior to the moment "when individuals no longer fully identify the kernel of their being with their particular social situation" when they begin to "experience themselves as forever 'out of joint" with that situation. See Slavoj Žižek, Against Human Rights, 34 New LEFT Rev. 115 (2005), http://newleftreview.org/II/34/slavoj-zizek-against-human-rights; see also ŽIžEK, supra note 1.

60. ŽıžEK, supra note 1 , at 149-50. "How and in what specific historical conditions does abstract universality itself become "a fact of (social) life?" Žižek asks. "This is the point of Marx's analysis of commodity fetishism: in a society in 
formulation-the transformative realization in actual social life of law as abstraction-would not be palatable for Kennedy, to whom abstraction (freedom, justice) must be overcome if one is to realize the contingent possibilities for change inherent in "how legality works" once the "false necessity" both of capitalism's legal form and of its commodity form have been exposed. ${ }^{61}$ For Žižek, however, it is symptomatic of a distinct way of thinking about both "organic poise" and how it can be disrupted that is attractive here precisely because (a) it allows us to think of capitalism as an aggregate phenomenon, and (b) it does not indulge concepts of false consciousness.

Marxists, says Žižek, have long harped on "the gap between the ideological appearance of the universal legal

which commodity exchange predominates, individuals in their daily lives relate to themselves, as well as to the objects they encounter, as contingent embodiments of abstract and universal notions." Id. When individuals cease to identify the reality of their being solely with the specifics of their circumstances, universality becomes "for itself" and "individuals experience themselves as forever 'out of joint' with regard to [their] situation.... In a given social structure, universality becomes 'for itself' ... in those individuals who lack a proper place in it." Id. On law and the "facts of life," see TomLINS, supra note 15, at $19-20$.

61. Kennedy, supra note 17 , at $951,956-57,991-92,999-1001$. Kennedy argues that "the indeterminacy of the internal criteria of legality is great enough as a matter of fact so that, for purposes of the kind of social theory Marxists are interested in, we must regard the notion of the commodity form as hopelessly imprecise." Id. at 999-1000. He concludes:

The commodity form in a particular economy is an artifact of a flexible human practice of legal adaptation that is adrift in time, so to speak, rather than directed along definite lines by guiding abstractions.... [W]e must be attentive to its particular course, accepting its historical contingency when viewed from the point of view of the aspiration to science in social theory. And though we may learn to understand that course of drift better than we now do, it won't be through the refinement of the notions of property and contract that define the commodity regime in the abstract. I conclude that a realist/institutionalist understanding of law destabilizes Marx's notion of the commodity mode of production in much the same way that it destabilizes the law of value. As I have interpreted it, this understanding of law is the enemy, in our understanding of social and economic life, of false necessity, in the same way that Marx's analysis of commodity fetishism is the enemy of false necessity.

Id. at 1000-01. 
form and the particular interests that effectively sustain it" while ignoring " $[\mathrm{t}]$ he counter-argument that the form is never a 'mere' form, but involves a dynamic of its own which leaves traces in the materiality of social life."62 Thus, standard Marxist argument treats "the form of universal [human] rights, equality, freedom, and democracy" simply as "a necessary but illusory expression of its concrete social content... exploitation and class domination." 63 But the counter-argument, that these forms are not mere appearances but have a power of their own, is far more subversive, for it presses upon "organic poise" an "articulation of actual socio-economic relations" that organic poise itself abstractly affirms, on behalf of those who have no place in it. ${ }^{64}$ "The mode of appearance of an abstract universality, its entering into actual existence, thus produces violence: it violently disrupts a preceding organic poise." 65

The reduction to "mere illusion" of that which can represent "a different actuality" is thus something to be avoided. "The key moment of any theoretical-and indeed ethical, political, and ... even aesthetic-struggle is the rise of universality out of the particular lifeworld."66 In such moments, "abstract universality" becomes "for itself," affirms its form, "not simply external to or above its particular context" but "inscribed within it."67 These are moments of plasticity "insofar as individuals no longer fully identify the kernel of their being with their particular social situation."68

"Capitalism as law," then, represents a relation of organic poise. But capitalism as law, no less than capitalism as religion, is a constellation saturated with tensions. Universality-for-itself can "perturb[ ] and affect[ ]" the

62. ŽIŽEK, supra note 1 , at 150.

63. Id. at 150-51.

64. Id.

65. Id. at 150 .

66. Id. at 152 .

67. $I d$.

68. Id. at 150-52. 
constellation from within. ${ }^{69}$ Its tensions can be exposed, and snapped.

69. Id. at 152 . 
